\title{
Leaf Gas Exchange Responses to Irrigation Timing and Nigari (Effluent of Salt Industries) of Sweet Pepper (Capsicum annuum L.) in Soilless Culture
}

Md. Jahedur Rahman, Haruhisa Inden ${ }^{1,3}$, and Masaaki Kirimura ${ }^{2}$

Department of Environment and Resource Sciences, Interdisciplinary Graduate School of Agriculture and Engineering, University of Miyazaki, Miyazaki 889-2192, Japan

Additional index words. photosynthesis, transpiration, stomatal conductance, light compensation point, leaf vapor pressure deficit

\begin{abstract}
There is increasing interest in reducing fertilizer cost and establishing proper irrigation management for sustainable vegetable production. Nigari, an effluent of salt industries, is cheaper than commercial fertilizers. Another important vegetable production factor is nutrient application timing to improve soilless cultivation in crops like sweet pepper. Therefore, this study evaluated the effects of nigari and nutrient solution application timing on leaf gas exchanges of sweet pepper cultivated under a soilless system. Treatments included three nigari rates [no nigari plus a standard nutrient solution as control, $2 \mathrm{~mL} \cdot \mathrm{L}^{-1}$ nigari + additional nitrogen-phosphorus-potassium $(\mathrm{N}-\mathrm{P}-\mathrm{K})$ to equal the standard, and $4 \mathrm{~mL} \cdot \mathrm{L}^{-1}$ nigari + additional $\mathrm{N}-\mathrm{P}-\mathrm{K}$ to equal the standard]. Three daily application timings $\left(T_{1}=0700 \mathrm{HR}+1500 \mathrm{HR}, T_{2}=0900 \mathrm{HR}+1500 \mathrm{HR}\right.$, and $\mathrm{T}_{3}=$ $0700 \mathrm{HR}+0900 \mathrm{HR}+1500 \mathrm{HR}$ ) were used for each nutrient solution. Leaf gas exchange parameters were studied during the vegetative and reproductive growth stages of sweet pepper cv. Papri new-E-red. Photosynthetic responses and its related parameters, namely transpiration (E), stomatal conductance $\left(g_{\mathrm{S}}\right)$, and maximum photosynthesis $\left(A_{\max }\right)$, were significantly affected by nigari rates and nutrient solution application timing. Photosynthesis-related parameters, E, $g_{\mathrm{S}}, \mathrm{A}_{\max }$, and initial slope of photosynthesis in response to light curve were the highest and light compensation point (LCP) and leaf vapor pressure deficit (LVPD) were the lowest at $2 \mathrm{~mL} \cdot \mathrm{L}^{-1}$ nigari compared with the control at both plant vegetative and reproductive growth stages. For nutrient solution application timing, the highest $\mathrm{E}, g_{\mathrm{S}}$, and $\mathrm{A}_{\max }$ were observed at $\mathrm{T}_{3}$ treatment at both plant growth stages. Furthermore, marketable yield of sweet pepper was the highest when $2 \mathrm{~mL} \cdot \mathrm{L}^{-1}$ nigari was applied at 0700,0900 , and $1500 \mathrm{HR}$ a day. Leaf gas exchange parameters showed that nutrient solution application timing of 0700,0900 , and $1500 \mathrm{HR}$ a day was better for obtaining high yield of sweet pepper under nigari treatment in soilless culture.
\end{abstract}

Sweet pepper (Capsicum annuum L.) is an economically important vegetable crop all over the world. It is often grown intensively in greenhouses. In the greenhouse, irrigation is necessary to ensure stable yields with high

\footnotetext{
Received for publication 21 June 2012. Accepted for publication 4 Sept. 2012.

This article is a portion of a $\mathrm{PhD}$ dissertation that will be submitted by Md. Jahedur Rahman at the University of Miyazaki, Japan.

We thank Dr. M. Mofazzal Hossain of the Horticulture at Bangabandhu Sheikh Mujibur Rahman Agricultural University, Bangladesh, for his valuable suggestions during preparing the manuscript. We also thank Kurokawa and Hanif Afzali for cooperation in collecting the data. We are grateful to Mr. Joshua Hansell for English editing.

${ }^{1}$ Professor.

${ }^{2}$ Assistant Professor.

${ }^{3}$ To whom reprint requests should be addressed; e-mail inden@cc.miyazaki-u.ac.jp.
}

the delivery of nutrient solution can affect water availability to plants and thus can directly affect fruit yield, fruit quality, and production costs. Understanding the timing of nutrient solution has therefore become increasingly important to achieve sustainable agriculture. Sustainable agricultural development depends on sound irrigation and water management, the main aim of which is, first, to satisfy crop water needs and, second, to maintain good soil aeration (McNiesh and Welch, 1985). Therefore, mistakes in application timing of nutrient solution may result in serious yield reduction. Furthermore, overirrigation and prolonged soil saturation can cause disease in plant roots or root rot. However, different irrigation timing may have an effect on yield by affecting leaf gas exchanges.

There is also increasing attention being given toward reducing the production cost of agricultural crops. Nigari application in soilless culture can lower production cost because it contains many macro- and micronutrients and can be an alternative fertilizer source. Nigari is an effluent of salt industries and cheaper than commercial fertilizers. It contains high amounts of calcium $\left(\mathrm{Ca}^{2+}\right)$, magnesium $\left(\mathrm{Mg}^{2+}\right)$, and other microelements that may have an effect on leaf gas exchange of sweet pepper. Nigari also contains some extent of sodium $\left(\mathrm{Na}^{+}\right)$that may impose mild salinity, but it contains some silicon $(\mathrm{Si})$ that may minimize the negative impact of salinity (Bradbury and Ahmad, 1990; Liang et al., 1996). However, the excess of salts in the soil solution and in the irrigation water causes the reduction of pepper fruit size (Navarro et al., 2002) and the increase of blossom-end rot incidence (Tadesse et al., 1999).

Photosynthetic rates depend on a number of factors such as age of the leaves (Connor et al., 1993), sink assimilate demand (Frageria, 1992), and availability of water as well as light and nutrients. Photosynthesis is also affected by different stress factors (Taiz and Zeiger, 2006). The capacity of the plant's photosynthetic apparatus is reduced in the presence of excess salts (Ashraf, 2001; RomeroAranda et al., 2001). In any case, the ultimate effect of salts on photosynthesis depends on the nature of the salts, their concentration, and the plant species. It is possible that low salinity increases photosynthesis, whereas high salinity reduces it. Nigari may have mild or low salinity as a result of the presence of $\mathrm{Na}^{+}$and may have an effect on leaf gas exchange in sweet pepper. There has been no research on nigari application and its impact on leaf gas exchange, although it is used as a supplemental liquid fertilizer in Japan. There is a need to encourage more sustainable agricultural practices, reducing inputs of fertilizers, while minimizing any negative impact on leaf gas exchange of crops like sweet pepper. Therefore, it is important to investigate the effect of nigari on leaf gas exchange in sweet pepper. In the present study, leaf gas exchange of sweet pepper plants was measured to determine the effects 
of nutrient solution application timing and nigari on $g_{\mathrm{S}}$, LVPD, and leaf photosynthetic rate of soilless greenhouse-grown sweet pepper plants.

\section{Materials and Methods}

Experimental site, plant materials, and growing conditions. A greenhouse experiment was conducted from Sept. 2011 to May 2012 at the Horticulture Farm in the University of Miyazaki, Miyazaki, Japan. The experiment was conducted in $15-\mathrm{L}$ pots and one plant was transplanted into each pot. Seedlings were transplanted into the pots on 12 Nov. 2011. Sweet pepper cv. Papri new-E-red (Marutane Seed Co., Kyoto, Japan) was used in this experiment based on its yield under high-temperature conditions (Rahman and Inden, 2012). One 15-cm, sixth-leaf stage, 8 -week-old seedling was transplanted into a $15-\mathrm{L}$ pot containing a 50:45:5 (v/v) mixture of coconut coir peat, perlite, and shodo (burned loam soil), respectively. Three replicates of three pots were tested for each treatment. Two edge rows were grown to reduce border effects. Nutrient solutions were applied to the plants continuously by a drip irrigation system. The $\mathrm{pH}$ and electrical conductivity (EC) of the nutrient solutions were controlled during application. Nutrient compositions, $\mathrm{EC}$, and $\mathrm{pH}$ for each treatment are shown in Table 1. Average minimum and maximum temperatures and relative humidity were $18 \pm 2{ }^{\circ} \mathrm{C}$ and $24 \pm 2{ }^{\circ} \mathrm{C}$ and $40 \% \pm 10 \%$ and $55 \% \pm 10 \%$, respectively, during the experiment. The temperatures were maintained by a heating system and exhaust fans in the greenhouse.

Experimental design and treatments. A randomized complete block design with three $x$ three factorial treatments and three replications were used in this study. Three plants served as an experimental unit. Two factors of this experiment were three nigari treatments (no nigari plus a standard nutrient solution as control, $2 \mathrm{~mL} \cdot \mathrm{L}^{-1}$ nigari + additional $\mathrm{N}-\mathrm{P}-\mathrm{K}$ to equal the standard, and $4 \mathrm{~mL} \cdot \mathrm{L}^{-1}$ nigari + additional $\mathrm{N}-\mathrm{P}-\mathrm{K}$ to equal the standard) and three nutrient solution application timings $\left(\mathrm{T}_{1}=\right.$ twice a day at $0700 \mathrm{HR}$ and $1500 \mathrm{HR} ; \mathrm{T}_{2}=$ twice a day at $0900 \mathrm{HR}$ and $1500 \mathrm{HR}$; and $\mathrm{T}_{3}=$ three times a day at $0700 \mathrm{HR}, 0900 \mathrm{HR}$, and $1500 \mathrm{HR}$ ). An equal volume of nutrient solution was applied for all the treatments and it was on an average $1.95 \mathrm{~L} / \mathrm{plant} /$ day. The standard nutrient

Table 1. Macro- and micronutrients, electrical conductivity (EC), and $\mathrm{pH}$ of different nigari treatments.

\begin{tabular}{llccccccc}
\hline & \multicolumn{9}{c}{ Macronutrients (meq. $\left.\mathrm{L}^{-1}\right)$} & & \multicolumn{1}{c}{$\mathrm{EC}$} \\
\cline { 2 - 7 } Nigari treatment & $\mathrm{NO}_{3}^{-}$ & Phosphorus & Potassium & Calcium & Magnesium & Sulfur & $\mathrm{pH}$ & $\left(\mathrm{dS} \cdot \mathrm{m}^{-1}\right)$ \\
\hline 0 (control) & 17.05 & 7.86 & 8.94 & 9.95 & 6.00 & 6.00 & $\approx 6.0$ & 2.8 \\
$2 \mathrm{~mL} \cdot \mathrm{L}^{-1}$ & 17.05 & 7.86 & 8.94 & 9.47 & 23.28 & 12.11 & $\approx 6.0$ & 3.5 \\
$4 \mathrm{~mL} \cdot \mathrm{L}^{-1}$ & 17.05 & 7.86 & 8.94 & 18.93 & 46.56 & 24.21 & $\approx 6.0$ & 3.9
\end{tabular}

Micronutrients $\left(\mu \mathrm{g} \cdot \mathrm{L}^{-1}\right)$

\begin{tabular}{lrccrccrc} 
& \multicolumn{10}{c}{} & Iron & Manganese & Zinc & Boron & Molybdenum & Copper & Sodium & Silicon \\
\hline 0 (control) & 3,000 & 1,000 & 100 & 500 & 25 & 30 & - & - \\
$2 \mathrm{~mL} \cdot \mathrm{L}^{-1}$ & 8,266 & 2,942 & 106 & 1,882 & 908 & - & 65,050 & 1,284 \\
$4 \mathrm{~mL} \cdot \mathrm{L}^{-1}$ & 16,532 & 5,884 & 212 & 3,764 & 1,816 & - & 130,100 & 2,568 \\
\hline
\end{tabular}

$30 \mathrm{~d}$ after start of the nigari treatments during the vegetative growth stage, $4 \mathrm{~mL} \cdot \mathrm{L}^{-1}$ nigari reduced $\mathrm{E}$ and $g_{\mathrm{S}}$ by $29 \%$ and $41 \%$, respectively, compared with the control, suggesting that the reduction in E was associated with the decreased $g_{\mathrm{S}}$ (Table 3 ). However, there was no significant difference in $\mathrm{E}$ between $2 \mathrm{~mL} \cdot \mathrm{L}^{-1}$ nigari and the control. However, significant differences were found in $g_{\mathrm{S}}$ between $2 \mathrm{~mL} \cdot \mathrm{L}^{-1}$ nigari and the control. It was found that $2 \mathrm{~mL} \cdot \mathrm{L}^{-1}$ nigari increased $\mathrm{E}$ and $g_{\mathrm{S}}$ by $11 \%$ and $16 \%$, respectively, compared with the control. This might be the result of differences in EC among the nigari treatments and the EC increased with increasing rate of nigari. A similar correlation between $\mathrm{E}$ and $g_{\mathrm{S}}$ under varied EC levels was reported in tomato by Romero-Aranda et al. (2001). High salinity $(0.5$ and $1 \% \mathrm{NaCl})$ and water stress also limited pepper plant gas exchanges and reduced transpiration (De Pascale et al., 2000). Our findings are consistent with their results, because nigari contains some $\mathrm{Na}^{+}$that might have imposed salinity stress on the plants when applied at $4 \mathrm{~mL} \cdot \mathrm{L}^{-1}$ nigari that reduced the $\mathrm{E}$ and $g_{\mathrm{S}}$. Furthermore, $2 \mathrm{~mL} \cdot \mathrm{L}^{-1}$ nigari might have mild salinity, but the $\mathrm{Si}$ might mitigate the adverse effect of salinity, thus improving the $\mathrm{E}$ and $g_{\mathrm{S}}$ in sweet pepper. Bradbury and Ahmad (1990) and Liang et al. (1996) reported that Si minimized the adverse effects of salinity in tomato.

Our results revealed that LVPD increased with increasing rate of nigari. The highest LVPD was found at $4 \mathrm{~mL} \cdot \mathrm{L}^{-1}$ nigari and the lowest at $2 \mathrm{~mL} \cdot \mathrm{L}^{-1}$ nigari. It was found that $2 \mathrm{~mL} \cdot \mathrm{L}^{-1}$ nigari reduced LVPD by $17 \%$ and $33 \%$ compared with the control and $4 \mathrm{~mL} \cdot \mathrm{L}^{-1}$ nigari, respectively. Negative responses of $\mathrm{E}$ and $g_{\mathrm{S}}$ to LVPD were found. Martínez and Roca (2001) found differences in LVPD in sweet pepper that negatively affected the E under different humidity conditions. Our trend of LVPD was consistent with their results when nigari was applied.

When measured during the reproductive growth stage, the nigari treatments significantly affected the $\mathrm{E}$ and $g_{\mathrm{S}}$. The highest $\mathrm{E}$ and $g_{\mathrm{S}}$ were found with $2 \mathrm{~mL} \cdot \mathrm{L}^{-1}$ nigari, which increased significantly by $9 \%$ and $8 \%$, respectively, compared with the control. However, the higher rate of nigari $\left(4 \mathrm{~mL} \cdot \mathrm{L}^{-1}\right)$ reduced $\mathrm{E}$ and $g_{\mathrm{S}}$ by $23 \%$ and $30 \%$, respectively, compared with the control. A smaller reduction of $\mathrm{E}$ and $g_{\mathrm{S}}$ was found with $4 \mathrm{~mL} \cdot \mathrm{L}^{-1}$ nigari in the reproductive growth stage than in the vegetative growth stage. This might be because of the plant's osmotic adjustment after prolonged exposure to high EC at $4 \mathrm{~mL} \cdot \mathrm{L}^{-1}$ nigari. Osmotic adjustment in plants is an important adaptation to water stress by decreasing the leaf water potential to compensate the lowering of water potential in the nutrient solution (Guerrier, 1996; Shannon et al., 1987). A similar trend of $\mathrm{E}$ and $g_{\mathrm{S}}$ was found in tomato under different EC levels by $\mathrm{Wu}$ and Kubota (2008). Nigari at $2 \mathrm{~mL} \cdot \mathrm{L}^{-1}$ improved $\mathrm{E}$ and $g_{\mathrm{S}}$ in the reproductive growth stage, although the EC of this treatment was a bit higher than the control. If the greater E observed in the reproductive than the 
Table 2. Composition of nigari analyzed by inductively coupled plasma emission spectroscopy.

\begin{tabular}{|c|c|c|c|c|c|c|c|c|c|c|c|c|}
\hline Oon & os & Pota & 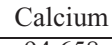 & Mas & $\mathrm{ar}$ & Irc & $\mathrm{N}$ & Zinc & Bo & Molybde & So & \\
\hline$m$ & 1 & 81 & 558 & 139,669 & 96,854 & 4,133 & 1,471 & 53 & 941 & 454 & 32,525 & 642 \\
\hline
\end{tabular}

Table 3. Effect of nigari concentrations and nutrient solution application timings on transpiration (E), leaf conductance $\left(g_{\mathrm{S}}\right)$, and leaf vapor pressure deficit (LVPD) in sweet pepper.

\begin{tabular}{|c|c|c|c|c|c|c|c|c|c|c|}
\hline \multirow[b]{2}{*}{ Treatment } & \multicolumn{5}{|c|}{ Vegetative growth stage } & \multicolumn{5}{|c|}{ Reproductive growth stage } \\
\hline & \multicolumn{2}{|c|}{$\begin{array}{c}\mathrm{E} \\
\left(\mathrm{mmol} \cdot \mathrm{m}^{-2} \cdot \mathrm{s}^{-1}\right)\end{array}$} & \multicolumn{2}{|c|}{$\begin{array}{c}g_{\mathrm{S}} \\
\left(\mathrm{mol} \cdot \mathrm{m}^{-2} \cdot \mathrm{s}^{-1}\right)\end{array}$} & $\begin{array}{l}\text { LVPD } \\
(\mathrm{kPa})\end{array}$ & \multicolumn{2}{|c|}{$\begin{array}{c}\mathrm{E} \\
\left(\mathrm{mmol} \cdot \mathrm{m}^{-2} \cdot \mathrm{s}^{-1}\right)\end{array}$} & \multicolumn{2}{|c|}{$\begin{array}{c}g_{\mathrm{S}} \\
\left(\mathrm{mol} \cdot \mathrm{m}^{-2} \cdot \mathrm{s}^{-1}\right)\end{array}$} & $\begin{array}{l}\text { LVPD } \\
(\mathrm{kPa})\end{array}$ \\
\hline \multicolumn{11}{|c|}{ Nigari concentration } \\
\hline 0 (control) & 3.18 & $a^{z}$ & 0.139 & $\mathrm{~b}$ & $1.52 \mathrm{~b}$ & 4.08 & $\mathrm{~b}$ & 0.199 & $\mathrm{~b}$ & $1.13 \mathrm{~b}$ \\
\hline $2 \mathrm{~mL} \cdot \mathrm{L}^{-1}$ & 3.53 & $\mathrm{a}$ & 0.161 & $\mathrm{a}$ & $1.26 \mathrm{c}$ & 4.44 & a & 0.214 & $\mathrm{a}$ & $1.06 \mathrm{~b}$ \\
\hline $4 \mathrm{~mL} \cdot \mathrm{L}^{-1}$ & 2.26 & $\mathrm{~b}$ & 0.082 & $\mathrm{c}$ & $1.87 \mathrm{a}$ & 3.12 & $\mathrm{c}$ & 0.140 & $\mathrm{c}$ & $1.29 \mathrm{a}$ \\
\hline \multicolumn{11}{|c|}{ Nutrient solution application timings (T) } \\
\hline $\mathrm{T}_{1}$ & 2.40 & $\mathrm{~b}$ & 0.092 & $\mathrm{c}$ & $1.78 \mathrm{a}$ & 3.16 & $\mathrm{c}$ & 0.142 & $\mathrm{c}$ & $1.32 \mathrm{a}$ \\
\hline $\mathrm{T}_{2}$ & 2.60 & $\mathrm{~b}$ & 0.116 & $\mathrm{~b}$ & $1.53 \mathrm{~b}$ & 3.72 & $b$ & 0.169 & $\mathrm{~b}$ & $1.12 \mathrm{~b}$ \\
\hline $\mathrm{T}_{3}$ & 3.96 & $\mathrm{a}$ & 0.174 & $\mathrm{a}$ & $1.33 \mathrm{~b}$ & 4.76 & $\mathrm{a}$ & 0.242 & $\mathrm{a}$ & $1.04 \mathrm{c}$ \\
\hline \multicolumn{11}{|l|}{$P$} \\
\hline Nigari & $<0$ & & $<0.0$ & & $<0.001$ & $<0$ & & $<0.0$ & & $<0.001$ \\
\hline $\mathrm{T}$ & & & $<0.0$ & & 0.002 & $<0$ & & $<0.0$ & & $<0.001$ \\
\hline Nigari $\times \mathrm{T}$ & & 08 & 0.0 & & 0.461 & & 10 & 0.4 & & $<0.001$ \\
\hline
\end{tabular}

${ }^{\text {z}}$ Means with different letter within the column is significantly different by Tukey's test at $P \leq 0.05$.

$P$ represents significance for analysis of variance of nigari, nutrient solution application timings $(\mathrm{T})$, and interaction of nigari $\times \mathrm{T}$.

vegetative growth stage was caused by the increased $g_{\mathrm{S}}$, the $\mathrm{E} / g_{\mathrm{S}}$ ratio, representing a driving force of transpiration rate, should have been similar. Therefore, the difference observed in $\mathrm{E} / g_{\mathrm{S}}$ may suggest that there were physiological changes between two stages such as acclimatization to mild salt stress resulting from nigari at $2 \mathrm{~mL} \cdot \mathrm{L}^{-1}$. Similarly, acclimatization of hydroponic tomato plants to salt stress and water deficit was observed by $\mathrm{Xu}$ et al. (1997). The LVPD in the reproductive growth stage increased with increasing rate of nigari and the highest LVPD was found with $4 \mathrm{~mL} \cdot \mathrm{L}^{-1}$ nigari. Meanwhile, the lowest LVPD was found with $2 \mathrm{~mL} \cdot \mathrm{L}^{-1}$ nigari, which was not significantly different from the control. However, $2 \mathrm{~mL} \cdot \mathrm{L}^{-1}$ nigari reduced LVPD by $6 \%$ and $17 \%$ compared with the control and $4 \mathrm{~mL} \cdot \mathrm{L}^{-1}$ nigari, respectively. A smaller reduction in LVPD at 2 $\mathrm{mL} \cdot \mathrm{L}^{-1}$ nigari compared with the control was noticed in the reproductive stage compared with the vegetative stage. This result indicated that the sweet pepper plants acclimatized after prolonged application of 2 $\mathrm{mL} \cdot \mathrm{L}^{-1}$ nigari.

Nutrient solution application timing had a significant effect on $\mathrm{E}$ and $g_{\mathrm{S}}$ when measured at $30 \mathrm{~d}$ after the start of treatment during vegetative growth (Table 3 ). Equal volumes (average $1.95 \mathrm{~L} /$ plant/day) of nutrient solution were applied everyday for all the treatments. The lowest $E$ was found with $T_{1}$, which was similar to that of $\mathrm{T}_{2}$. Meanwhile, $\mathrm{T}_{3}$ exhibited the highest E. Similarly, the highest $g_{\mathrm{S}}$ was found from $T_{3}$ and the lowest from $T_{1}$. The relatively low $\mathrm{E}$ and $g_{\mathrm{S}}$ in $\mathrm{T}_{1}$ may be because it created a mild water-stress condition at noon compared with the other treatments. Niu et al. (2006) reported that photosynthesis, E, and $g_{\mathrm{S}}$ of some bedding plants were reduced with decreasing moisture content in the growth substrate. Our results are consistent with their findings. Greater leaching and evaporation might be created in $\mathrm{T}_{1}$ and $\mathrm{T}_{2}$ as a result of the application of a higher volume of water at a given time. In fact, $T_{3}$ treatment supplied adequate water and leaching was not observed. Before noon plants in $\mathrm{T}_{3}$ received water, which might explain the increase $\mathrm{E}$ and $g_{\mathrm{S}}$. Sweet peppers require relatively moist soils and an adequate water supply (Doorenbos and Kassam, 1979). Irrigation timing at $0900 \mathrm{HR}$ or noon is important, because at that time, air temperature is higher than earlier in the day. LVPD showed a significant difference as a result of nutrient solution application timing. The $T_{3}$ had the lowest LVPD resulting in higher $\mathrm{E}$ and $g_{\mathrm{S}}$. Therefore, exposure to low LVPD may be conducive to growth by keeping stomata open for gas exchange. Cunningham (2005) reported a decrease in net photosynthesis with increasing LVPD in tropical tree species. Jaimez and Rada (2011) reported that Capsicum chinensis plants under full sunlight showed a slight tendency to decrease $g_{\mathrm{S}}$ as LVPD increased, which is consistent with the results of our present experiment under different timings of nutrient solution application.

During the reproductive growth stage, $\mathrm{T}_{3}$ had greater $\mathrm{E}$ and $g_{\mathrm{S}}$ and lower LVPD than the other nutrient solution application timings. However, the $\mathrm{T}_{3}$ had greater $\mathrm{E}$ and $g_{\mathrm{S}}$ and lower LVPD in the reproductive growth stage than those of measured during the vegetative growth stage. The overall differences in E, $g_{\mathrm{S}}$, and LVPD among the treatments were smaller during the reproductive growth stage than those during the vegetative growth stage. Our results indicated that the time of day when irrigation was applied affected the gas exchange of the sweet peppers. Russo (2011) reported that the irrigation application timing in field-grown sweet pepper was better at 1000 HR or 1400 HR.

Significant interactions between nigari rates and nutrient solution application timing were found for $\mathrm{E}$ and $g_{\mathrm{S}}$ but not for LVPD during the vegetative growth stage (data not shown). Similarly, interactions for $\mathrm{E}$ and LVPD were significant but not significant for $g_{\mathrm{S}}$ during the reproductive growth stage. However, the highest values for $\mathrm{E}$ and $g_{\mathrm{S}}$ and the lowest value for LVPD were found in $\mathrm{T}_{3}$ under $2 \mathrm{~mL} \cdot \mathrm{L}^{-1}$ nigari at both of the growth stages (data not shown).

Photosynthetic responses. Results revealed that $2 \mathrm{~mL} \cdot \mathrm{L}^{-1}$ nigari had the highest photosynthetic rate compared with $4 \mathrm{~mL} \cdot \mathrm{L}^{-1}$ nigari and the control during both of the vegetative and reproductive plant growth stages (Fig. 1). In fact, nigari contains some $\mathrm{Na}^{+}$that might have imposed mild salinity stress on pepper at $4 \mathrm{~mL} \cdot \mathrm{L}^{-1}$ nigari, and $\mathrm{EC}$ level in $4 \mathrm{~mL} \cdot \mathrm{L}^{-1}$ nigari was higher than the other treatments. Romero-Aranda et al. (2001) observed different responses in leaf gas exchange characteristics to different $\mathrm{NaCl}$ concentrations in tomato plants. Closure of stomata in the presence of increasing concentration of salts is a way for plants to reduce water losses. This, however, affects the antenna system of chloroplasts, the biochemical reactions that take place in them, and the entire system of energy transformation in chloroplasts (Iyengar and Reddy, 1996). Photosynthesis may have been reduced in $4 \mathrm{~mL} \cdot \mathrm{L}^{-1}$ nigari as a result of this phenomenon. Xu et al. (1995) reported that the net photosynthetic rate in tomato leaves increased at EC $4.0 \mathrm{dS} \cdot \mathrm{m}^{-1}$ compared with the control of $2.0 \mathrm{dS} \cdot \mathrm{m}^{-1}$ with plants were grown with NFT (nutrient film technique) and rock wool systems. In our study, $\mathrm{EC}$ of $2 \mathrm{~mL} \cdot \mathrm{L}^{-1}$ nigari was $3.9 \mathrm{dS} \cdot \mathrm{m}^{-1}$ that increased photosynthetic characteristics in sweet pepper plants. Similar responses to nigari were found when measured at the reproductive plant growth stage. However, $2 \mathrm{~mL} \cdot \mathrm{L}^{-1}$ nigari improved the photosynthetic rate of sweet pepper at both of the growth stages.

Nutrient solution application timing showed a significant effect on photosynthetic light response during the vegetative and reproductive growth stages (Fig. 2). Among the timing treatments, $T_{3}$ had the highest photosynthetic rate compared with the other timings at the vegetative growth and reproductive growth stages. In fact, $\mathrm{E}$ and $g_{\mathrm{S}}$ were the highest at both of the growth stages with $\mathrm{T}_{3}$ and the photosynthetic light response increased. Reduced $g_{\mathrm{S}}$ results in a decrease in uptake of $\mathrm{CO}_{2}$ that can be used in carboxylation reactions (Brugnoli and Björkman, 1992) and higher $g_{\mathrm{S}}$ in plants increases the diffusion of $\mathrm{CO}_{2}$ in the leaves and thus increases the rate of photosynthesis.

$A_{\text {max }}$, light compensation point, and initial slope of photosynthesis in response to light. During the vegetative growth stage, high concentration of nigari $\left(4 \mathrm{~mL} \cdot \mathrm{L}^{-1}\right)$ reduced the $\mathrm{A}_{\max }$ and initial slope by $24.4 \%$ and 

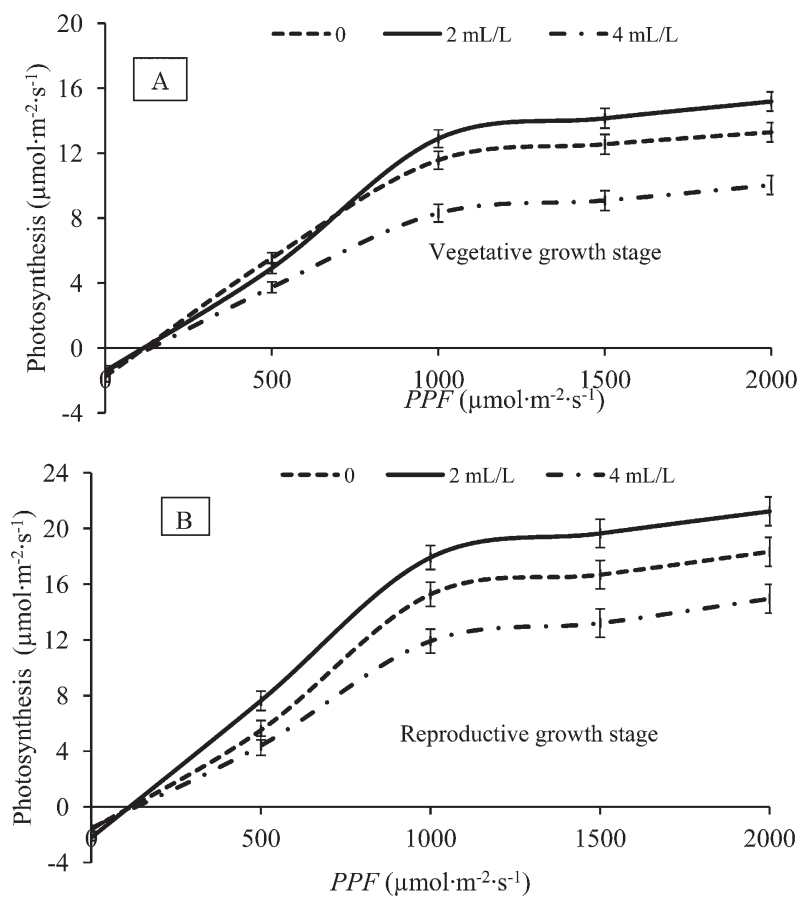

Fig. 1. Effect of different nigari concentrations on photosynthetic rate under different photosynthetic photon flux $(P P F)$ at vegetative $(\mathbf{A})$ and reproductive $(\mathbf{B})$ growth stages of sweet pepper. 0 (control), 2 , and $4 \mathrm{~mL} \cdot \mathrm{L}^{-1}$ represent three concentrations of nigari used in the experiment. Vertical bars represent the SE of the treatment means.
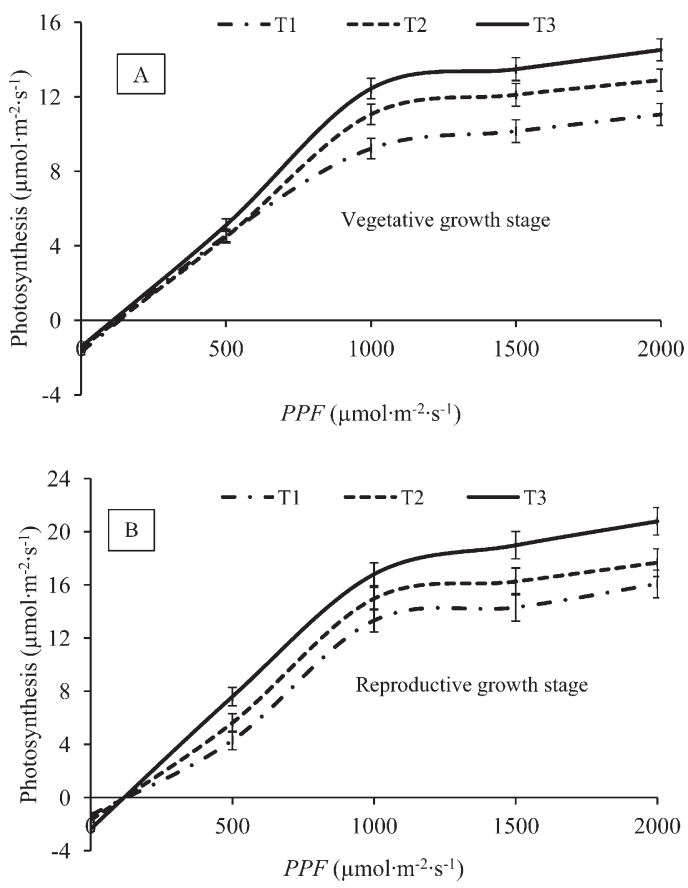

Fig. 2. Effect of different nutrient solution application timings on photosynthetic rate under different photosynthetic photon flux $(P P F)$ at vegetative $(\mathbf{A})$ and reproductive $(\mathbf{B})$ growth stages of sweet pepper. $\mathrm{T}_{1}=$ twice a day at $0700 \mathrm{HR}$ and $1500 \mathrm{HR} ; \mathrm{T}_{2}=$ twice a day at $0900 \mathrm{HR}$ and $1500 \mathrm{HR} ;$ and $_{3}=$ three times a day at $0700 \mathrm{HR}, 0900 \mathrm{HR}$, and $1500 \mathrm{HR}$. Vertical bars represent the SE of the treatment means.

$14.3 \%$, respectively, compared with the control (Table 4). Similarly, LCP increased with increasing the rate of nigari. The lower initial slope observed at $4 \mathrm{~mL} \cdot \mathrm{L}^{-1}$ nigari indicated a lower efficiency of photosynthesis under low light conditions, and the greater LCP at the same treatment indicated a greater respiration rate than those of $2 \mathrm{~mL} \cdot \mathrm{L}^{-1}$ nigari and the control. This might be due to higher EC in $4 \mathrm{~mL} \cdot \mathrm{L}^{-1}$ nigari, and a similar correlation was observed in tomato under moderate and high $\mathrm{EC}$ in the nutrient solution by $\mathrm{Wu}$ and Kubota (2008). However, we observed significantly increased vegetative growth (stem length and leaf size) in sweet pepper (data not shown) in the plants in $2 \mathrm{~mL} \cdot \mathrm{L}^{-1}$ nigari, which may be attributed to higher photosynthetic efficiency and lower respiration. During the reproductive growth stage, the $\mathrm{A}_{\max }$ and initial slope in $2 \mathrm{~mL} \cdot \mathrm{L}^{-1}$ nigari were significantly higher than that in $4 \mathrm{~mL} \cdot \mathrm{L}^{-1}$ nigari and the control. The LCP was significantly lower in $2 \mathrm{~mL} \cdot \mathrm{L}^{-1}$ nigari but not significant with the control. This might be the result of higher EC and mild salinity stress that might have been imposed by $4 \mathrm{~mL} \cdot \mathrm{L}^{-1}$ nigari. The reduction of the rate of photosynthesis in the presence of excess salts may be explained by the rapid aging of leaves and changes in activities and actions of other enzymes, besides RuBisCO, that are involved in photosynthesis, which leads to changes in the structure of the entire cell cytoplasm of photosynthetic tissues (Maksimovic and Ilin, 2012). At the same time, slower transport of the products of photosynthesis from the source to the sink also leads to a slowing of photosynthesis (Iyengar and Reddy, 1996). The lower rate of nigari performed better and it promoted reproductive growth of sweet pepper plants. The $A_{\max }$ was relatively greater in the reproductive growth stage than in the vegetative growth stage within the same nigari treatments. The initial slope of the photosynthetic response curve decreased with increasing nigari rate for the vegetative growth and the reproductive growth stages. The changes observed between the two stages may be caused by the plant acclimatization to the increased nigari rates, as observed for $\mathrm{E}$ and $g_{\mathrm{S}}$ (Table 3). Another possible reason for greater maximum photosynthetic rate in the reproductive stage than that in the vegetative stage is the increased sink strength of the plant during the reproductive growth (Ho, 1988).

Among the nutrient application timing treatments, $T_{3}$ had the highest $A_{\max }$ and initial slope with lower LCP compared with the other timings at both growth stages. At both growth stages, $\mathrm{E}$ and $g_{\mathrm{S}}$ were the highest at $\mathrm{T}_{3}$ and thus photosynthetic light response parameters were increased. Irrigation timing in sweet pepper plants is an important factor for improvement of photosynthetic response.

Significant interactions between nigari rates and nutrient solution application timing were found for LCP at both growth stages, but were not significant for $\mathrm{A}_{\max }$ and initial slope (data not shown). The lowest interaction value for LCP was found at $2 \mathrm{~mL} \cdot \mathrm{L}^{-1}$ nigari under $\mathrm{T}_{3}$ treatment at both of the growth stages (data not shown).

Yield. The highest yield was obtained from nigari at $2 \mathrm{~mL} \cdot \mathrm{L}^{-1}$, which was not significantly different from the control (Fig. 3). This might be the result of the higher rate of photosynthesis at $2 \mathrm{~mL} \cdot \mathrm{L}^{-1}$ nigari compared with the other treatments. Colla et al. (2006) found decreased yield in grafted watermelon with increasing salinity in the nutrient solution. 
Table 4. Effect of nigari concentrations and nutrient solution application timings on maximum photosynthesis $\left(\mathrm{A}_{\max }\right)$, light compensation point $(\mathrm{LCP})$, and initial slope of photosynthesis in response of light in sweet pepper.

\begin{tabular}{|c|c|c|c|c|c|c|c|c|c|c|c|c|}
\hline \multirow[b]{2}{*}{ Treatment } & \multicolumn{6}{|c|}{ Vegetative growth stage } & \multicolumn{6}{|c|}{ Reproductive growth stage } \\
\hline & \multicolumn{2}{|c|}{$\begin{array}{c}\mathrm{A}_{\max } \\
\left(\mu \mathrm{mol} \cdot \mathrm{m}^{-2} \cdot \mathrm{s}^{-1}\right)\end{array}$} & \multicolumn{2}{|c|}{$\mathrm{LCP}$} & \multicolumn{2}{|c|}{$\begin{array}{l}\text { Initial } \\
\text { slope }\end{array}$} & \multicolumn{2}{|c|}{$\begin{array}{c}\mathrm{A}_{\max } \\
\left(\mu \mathrm{mol} \cdot \mathrm{m}^{-2} \cdot \mathrm{s}^{-1}\right)\end{array}$} & \multicolumn{2}{|c|}{ LCP } & \multicolumn{2}{|c|}{$\begin{array}{l}\text { Initial } \\
\text { slope }\end{array}$} \\
\hline \multicolumn{13}{|c|}{ Nigari concentration } \\
\hline 0 (control) & 13.28 & $a^{z}$ & 66.24 & $\mathrm{~b}$ & 0.007 & a & 18.33 & $\mathrm{ab}$ & 59.35 & $\mathrm{~b}$ & 0.010 & \\
\hline $2 \mathrm{~mL} \cdot \mathrm{L}^{-1}$ & 15.18 & $\mathrm{a}$ & 59.40 & $\mathrm{~b}$ & 0.009 & $\mathrm{a}$ & 21.23 & $\mathrm{a}$ & 54.99 & $\mathrm{~b}$ & 0.012 & \\
\hline $4 \mathrm{~mL} \cdot \mathrm{L}^{-1}$ & 10.03 & $\mathrm{~b}$ & 92.16 & $\mathrm{a}$ & 0.006 & $\mathrm{~b}$ & 14.95 & $\mathrm{~b}$ & 78.46 & $\mathrm{a}$ & 0.008 & b \\
\hline \multicolumn{13}{|c|}{ Nutrient solution application timing $(\mathrm{T})$} \\
\hline $\mathrm{T}_{1}$ & 11.06 & b & 94.29 & $\mathrm{a}$ & 0.006 & $\mathrm{~b}$ & 16.07 & $\mathrm{~b}$ & 77.65 & $\mathrm{a}$ & 0.009 & \\
\hline $\mathrm{T}_{2}$ & 12.90 & $\mathrm{ab}$ & 68.97 & $\mathrm{~b}$ & 0.007 & $a b$ & 17.67 & $a b$ & 62.16 & $\mathrm{~b}$ & 0.010 & \\
\hline $\mathrm{T}_{3}$ & 14.53 & $\mathrm{a}$ & 54.54 & $\mathrm{c}$ & 0.008 & $\mathrm{a}$ & 20.78 & $\mathrm{a}$ & 52.99 & $\mathrm{c}$ & 0.011 & \\
\hline \multicolumn{13}{|l|}{$P$} \\
\hline Nigari & \multicolumn{2}{|c|}{0.001} & \multicolumn{2}{|c|}{$<0.001$} & \multicolumn{2}{|c|}{0.001} & \multicolumn{2}{|c|}{0.007} & \multicolumn{2}{|c|}{$<0.001$} & \multicolumn{2}{|l|}{0.012} \\
\hline $\mathrm{T}$ & \multicolumn{2}{|c|}{0.008} & \multicolumn{2}{|c|}{$<0.001$} & \multicolumn{2}{|c|}{0.020} & \multicolumn{2}{|c|}{0.029} & \multicolumn{2}{|c|}{$<0.001$} & \multicolumn{2}{|l|}{0.039} \\
\hline Nigari $\times T$ & \multicolumn{2}{|c|}{0.953} & \multicolumn{2}{|c|}{$<0.001$} & \multicolumn{2}{|c|}{0.980} & \multicolumn{2}{|c|}{0.944} & \multicolumn{2}{|c|}{0.011} & \multicolumn{2}{|l|}{0.985} \\
\hline
\end{tabular}

${ }^{\mathrm{z}}$ Means with different letters within the column are significantly different by Tukey's test at $P \leq 0.05$.

$P$ represents significance for analysis of variance of nigari, nutrient solution application timings $(\mathrm{T})$, and interaction of nigari $\times \mathrm{T}$.

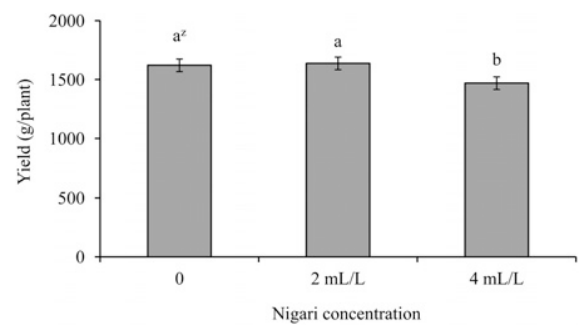

Fig. 3. Effect of different nigari concentrations on yield of sweet pepper. 0 (control), 2, and $4 \mathrm{~mL} \cdot \mathrm{L}^{-1}$ represent the three concentrations of nigari used in the experiment. Vertical bars represent the SE of the treatment means. ${ }^{\mathrm{z}}$ Means with different letters are significantly different by Tukey's test at $P \leq 0.05$.

For nutrient solution application timings, the highest yield was obtained when nutrient solution was applied three times a day $\left(\mathrm{T}_{3}\right)$ (Fig. 4). Nutrient solution application time could affect the yield of sweet pepper.

Significant interactions between nigari rate and nutrient solution application timing were found for yield and the highest yield was found at $\mathrm{T}_{3}$ under $2 \mathrm{~mL} \cdot \mathrm{L}^{-1}$ nigari which was statistically similar to that of $\mathrm{T}_{3}$ under the control (data not shown).

\section{Conclusion}

The photosynthetic rate and transpirational responses of sweet pepper cv. Papri new-E-red plants were affected by nigari rate and nutrient solution application timing at both vegetative and reproductive plant growth stages. During vegetative and reproductive growth, photosynthesis, transpiration, and their related parameters were the highest at $2 \mathrm{~mL} \cdot \mathrm{L}^{-1}$ nigari. The relatively sensitive responses to nigari of leaf gas exchange rates and its related parameters observed during the vegetative and reproductive growth stages suggest that the application of lower doses of nigari $\left(2 \mathrm{~mL} \cdot \mathrm{L}^{-1}\right)$ should be suitable, because it could improve the overall plant growth by increasing photosynthesis and transpiration.
Brugnoli, E. and O. Björkman. 1992. Chloroplast movements in leaves, Influence on chlorophyll fluorescence and measurements of lightinduced absorbance changes related to $\mathrm{pH}$ and zeaxanthin formation. Photosynth. Res. 32:2335.

Colla, G., Y. Roupahel, M. Cardarelli, and E. Rea. 2006. Effect of salinity on yield, fruit quality, leaf gas exchanges and mineral composition of grated water melon plants. HortScience 41:622-627.

Connor, D.J., A.J. Hall, and V.O. Sadras. 1993. Effect of nitrogen content on the photosynthetic characteristics of sunflower leaves. Aust. J. Plant Physiol. 20:1-263.

Cunningham, S.C. 2005. Photosynthetic responses to vapour pressure deficit in temperate and tropical evergreen rainforest trees of Australia. Oecologia 142:521-528.

De Pascale, S., C. Ruggiero, and G. Barbieri. 2000. Effects of irrigating pepper (Capsicum annuиm $\mathrm{L}$.) plants with saline water on plant growth, water use efficiency, and marketable yield. Acta Hort. 537:687-695.

Doorenbos, J. and A.H. Kassam. 1979. Yield response to water. Food and Agriculture Organization. Irrigation and drainage pepper No. 33. FAO, Rome, Italy.

Dorji, K., M.H. Behboudian, and J.A. ZegbeDominguez. 2005. Water relations, growth, yield, and fruit quality of hot pepper under deficit irrigation and partial root zone drying. Sci. Hort. 104:137-149.

Frageria, N.K. 1992. Photosynthesis, p. 55-64. In: Maximizing crop yields. Marcel Dekker.

Fig. 4. Effect of different nutrient solution application timings on yield of sweet pepper. $\mathrm{T}_{1}=$ twice a day at $0700 \mathrm{HR}$ and $1500 \mathrm{HR} ; \mathrm{T}_{2}=$ twice a day at $0900 \mathrm{HR}$ and $1500 \mathrm{HR}$; and $\mathrm{T}_{3}=$ three times a day at $0700 \mathrm{HR}, 0900 \mathrm{HR}$, and $1500 \mathrm{HR}$. Vertical bars represent the SE of the treatment means. ${ }^{\mathrm{z}}$ Means with different letters are significantly different by Tukey's test at $P \leq 0.05$.

For nutrient solution application timings, leaf gas exchange rates showed that nutrient solution applied three times $\left(\mathrm{T}_{3}\right)$ was better during both growth stages, and it could improve photosynthetic rates and related parameters while sustaining yields. Finally, we can suggest that $2 \mathrm{~mL} \cdot \mathrm{L}^{-1}$ nigari can improve leaf gas exchanges, which consequently led to higher yield when applied at 0700 , 0900, and 1500 HR per day. These results provide useful information to the growers for selecting a nutrient solution application timing and a suitable nigari rate in soilless greenhouse-grown sweet pepper.

\section{Literature Cited}

Arzani, K., D. Arzani, and G.S. Wood. 2000. Influence of first season application of paclobutrazol, root-pruning and regulated deficit irrigation on second season flowering and fruiting of mature 'Sundrop' apricot trees. Acta Hort. 516: $75-82$.

Ashraf, M. 2001. Relationships between growth and gas exchange characteristics in some salttolerant amphidiploid Brassica species in relation to their diploid parents. Environ. Exp. Bot. 45:155-163.

Bradbury, M. and R. Ahmad. 1990. The effect of silicon on the growth of Prosopis juliflora growing in saline soil. Plant Soil 125:71-78.
Grant, O.M., M. Stoll, and H.G. Jones. 2004. Partial root zone drying does not affect fruit yield of raspberries. J. Hort. Sci. Biotechnol. 79:125-130.

Guerrier, G. 1996. Fluxes of $\mathrm{Na}^{+}, \mathrm{K}^{+}$, and $\mathrm{Cl}^{-}$, and osmotic adjustment in Lycopersicon pimpinellifolium and $L$. esculentum during short-and long-term exposures to $\mathrm{NaCl}$. Physiol. Plant. 97:583-591.

Ho, L.C. 1988. Metabolism and compartmentation of imported sugars in sink organs in relation to sink strength. Annu. Rev. Plant Physiol. Plant Mol. Biol. 39:355-378.

Hutton, R. 2000. Improving the water use efficiency of citrus at Yanco Agricultural Institute, Yanco NSW 2703, Australia. Farmers' NewsletterHorticulture 184:47-49.

Iyengar, E.R.R. and M.P. Reddy. 1996. Photosynthesis in high salt-tolerant plants, p. 56-65. In: Pesserkali, M. (ed.). Hand book of photosynthesis. Marcel Dekker, Baten Rose.

Jaimez, R.E. and F. Rada. 2011. Gas exchange in sweet pepper (Capsicum chinense Jacq) under different light conditions. J. Agr. Sci. 3:134142.

Kang, S., H. Xiaotao, I. Goodwin, and P. Jerie. 2002. Soil water distribution, water use, and yield response to partial rootzone drying under a shallow groundwater table condition in a pear orchard. Sci. Hort. 92:277-291.

Kirda, C., M. Cetin, Y. Dasgan, S. Topcu, H. Kaman, B. Ekici, M.R. Derici, and A.I. Ozguven. 2004. Yield response of greenhouse grown tomato to partial root drying and conventional deficit irrigation. Agr. Water Mgt. 69:191-201

Liang, Y.C., Q.R. Shen, Z.G. Shen, and T.S. Ma. 1996. Effects of silicon on salinity tolerance of two barley cultivars. J. Plant Nutr. 19:173183.

Maksimovic, I. and Ž. Ilin. 2012. Effects of salinity on vegetable growth and nutrients uptake, $\mathrm{p}$. 180. In: Lee, T.S. (ed.). Irrigation systems and 
practices in challenging environments. $<$ http:// www.intechopen.com/books/irrigation-systemsand-practices-in-challenging-environments/ effects-of-salinity-on-vegetable-growth-andnutrients-uptake $>$.

Martínez, P.F. and D. Roca. 2001. Regulation of air humidity and effects on mineral levels and blossom-end rot incidence in pepper fruits. Acta Hort. 559:407-412.

McNiesh, C.M. and N.C. Welch. 1985. Trickle irrigation requirement for strawberries in coastal California. J. Amer. Soc. Hort. Sci. 110:714-718.

Navarro, J.M., C. Garrido, M. Carvajal, and V. Martinez. 2002. Yield and fruit quality of pepper plants under sulphate and chloride salinity. J. Hort. Sci. Biotechnol. 77:52-57.

Niu, G., D.S. Rodriguez, and Y.T. Wang. 2006 Impact of drought and temperature on growth and leaf gas exchange on six bedding plant species under greenhouse condition. HortScience 41:1408-1411.

Rahman, M.J. and H. Inden. 2012. Effect of nutrient solution and temperature on capsaicin content and yield contributing characteristics in six sweet pepper (Capsicum annuum L.) cultivars. J. Food Agr. Environ. 10:524-529.

Romero, P., P. Botia, and F. Garcia. 2004. Effects of regulated deficit irrigation under subsurface drip irrigation conditions on water relations of mature almond trees. Plant Soil 260:155-168

Romero-Aranda, R., T. Soria, and J. Cuartero. 2001. Tomato plant-water uptake and plantwater relationships under saline growth conditions. Plant Sci. 160:265-272.

Russo, V.M. 2011. Irrigation frequency and timing influence pepper yields. J. Crop Improv. 25: 540-549.

Shannon, M.C., J.W. Gronwald, and M. Tal. 1987. Effects of salinity on growth and accumulation of organic and inorganic ions in cultivated and wild tomato species. J. Amer. Soc. Hort. Sci. 112:416-423.

Tadesse, T., M.A. Nichols, and K.J. Fisher. 1999 Nutrient conductivity effects on sweet pepper plants grown using a nutrient film technique 2 .
Blossom-end rot and fruit mineral status. N. Z. J. Crop Hort. Sci. 27:239-247.

Taiz, L. and E. Zeiger. 2006. Plant physiology. 4th Ed. Sinauer Associates, Inc.

Van Hooijdonk, B.M., K. Dorji, and M.H. Behboudian. 2004. Responses of 'Pacific Rose' apple to partial rootzone drying and to deficit irrigation. Eur. J. Hort. Sci. 69:104 110

Wu, M. and C. Kubota. 2008. Effects of electrical conductivity of hydroponic nutrient solution on leaf gas exchange of five greenhouse tomato cultivars. HortTechnology 18:271-277.

Xu, H.L., L. Gauthier, and A. Gosselin. 1995. Effects of fertigation management on growth and photosynthesis of tomato plant grown in peat, rock wool and NFT. Sci. Hort. 63 : $11-20$.

Xu, H.L., L. Gauthier, and A. Gosselin. 1997. Greenhouse tomato photosynthetic acclimation to water deficit and response to salt accumulation in the substrate. J. Jpn. Soc. Hort. Sci. 65:777784 